\title{
Genetic polymorphism of CSN2 gene in Banat White and Carpatina goats
}

\author{
Szilvia Kusza1,2凶, Daniela Elena Ilie,3, Maria Sauer¹, Krisztina Nagy², Irina Patras ${ }^{1}$ and Dinu \\ Gavojdian'
}

'Research and Development Station for Sheep and Goats Caransebes, Academy for Agricultural and Forestry Sciences, Caransebes, Romania; ${ }^{2}$ Institute of Animal Science, Biotechnology and Nature Conservation, University of Debrecen, Debrecen, Hungary; ${ }^{3}$ Research and Development Station for Bovine Arad, Academy for Agricultural and Forestry Sciences,Arad, Romania

The main objective of the current study was to obtain preliminary results on genetic polymorhism of $A$ and $C$ variants at the CSN2 locus in indigenous Romanian goat (Banat White, Carpatina) breeds using a rapid and efficient genotyping method, TaqMan assay (Applied Biosystems, USA). Hair follicle samples were taken from 73 Banat White and 82 Carpatina purebred goats from Arad, Caras-Severin and Timis counties. After the optimization of the genotyping assay it was found that the most frequent allele at the CSN2 locus was $C$ in Banat White breed, while $\operatorname{CSN} 2{ }^{*} A$ and $C S N 2 * C$ showed similar frequencies in Carpatina breed $(0.51$ and 0.49 , respectively). All three genotypes were detected in the two studied breeds, however, AA was the least frequent, especially in Banat White. The studied polymorphisms are potential markers for milk production in the studied breeds and the results will be useful in future works aimed at identifying possible associations with milk production traits, in order to test the feasibility of producing hypoallergenic organic goat milk.

Key words: beta-casein gene, goats, polymorphism, Banat White, Carpatina, hypoallergenic milk

Received: 10 February, 2016; revised: 24 March, 2016; accepted: 18 May, 2016; available on-line: 06 July, 2016

\section{INTRODUCTION}

There is limited information about the genetic background of indigenous goat breeds reared in Romania. The goat farming sector in Romania has been rapidly developing for the last decade. There are 1.362.804 goats in Romania according to the reports of the Romanian Ministry of Agriculture and Rural Development for the year 2015. Overall, the national goat flock in Romania increased by over $40 \%$, compared to year 1990 . Furthermore, Romania has a pasture surface of 4.9 million hectares (roughly $30 \%$ of the country surface), which could sustain a flock of up to 16 million breeding sheep and goats (Dragomir, 2009). Goats are being reared in Romania predominantly under extensive low-input production systems, with the production being oriented primarily towards milk, while the kid meat is regarded as a marginal product. Nowadays, goats are being reared in Romanian in over 130.000 farming units (Raducuta et al., 2012).

The breed structure is dominated by the indigenous unimproved Carpatina, which represents over 90\% of the goats reared in Romania. The Carpatina goat is regarded as low performing, however the breed has a remarkable organic resistance and adaptation. Reports con- cerning the breed's performance showed modest production levels, with milk yields estimates of 220 to $350 \mathrm{~kg} /$ lactation, litter size of $130-160 \%$ and growth rates in kids ranging between 90 and $110 \mathrm{~g} /$ day (Padeanu, 2001; Pascal et al., 2011). The second indigenous goat breed of Romania, is the better performing Banat's White, which is currently listed as endangered and included in a genetic conservation program, with a census of 1.002 purebred does, reared in 5 farms. The Banat's White has a milk production of $370-400 \mathrm{~kg} /$ lactation and is highly prolific, with an average litter size of $200-225 \%$ (Voiaet al., 2011).

Genetic improvement schemes and conservation plans are becoming more and more important in each country for all species. As for the goat breeds, polymorphism of milk proteins, which are related to milk chemical composition and processing properties, as well as its biological characteristics has been well-studied worldwide (Martin et al., 2002; Vinesh et al., 2013). However, there are very few studies done in Romania (Zaulet et al., 2008; Vlaic et al., 2010), mostly using isoelectrofocusing (IEF) aiming the genetic polymorhism of milk protein genes, especially $\beta$-casein (CSN2).

The goat casein gene cluster region spans about 250 $\mathrm{kb}$ on chromosome 6 (Hayes et al., 1993). The CSN2 encoding gene consists of 9 exons (Roberts et al., 1992; Rijnkels 2002; Cosenza et al., 2005). Like in other ruminants, the caseins in goats also show complex and high qualitative and quantitative variability, they can be characterised by several genetic polymorphisms (Martin et al., 2002). Different methods were developed for identification of genetic variants of the goat CSN2 locus at the DNA level: single-strand conformation polymorphism (SSCP) (Chessa et al., 2005; Caroli et al., 2006), allelespecific-PCR (Ramunno et al., 1995), and PCR- restriction fragment length polymorhism (RFLP) (Cosenza et al., 2005). Seven out of ten autosomal alleles: $A, A 1, C$, $C 1, E, O$ and $O^{\prime}$ were characterized at DNA level while $\mathrm{B}$ and $\mathrm{D}$ alleles were described only at protein level until now (Mahe \& Grosclaude, 1993; Neveu et al., 2002; Galliano et al., 2004; Cosenza et al., 2005; Caroli et al., 2006; Chianese et al., 2007; Chessa et al., 2005, 2008; Tortorici et al., 2014). The genetic variants $A, A 1, B, C, C 1, D$, and $E$ were found to be associated with normal $\beta$ casein content (5 g/L per allele) (Roberts et al.,1992; Mahé

\footnotetext{
$\triangle$ e-mail: kusza@agr.unideb.hu
}

Abbreviations: CSN2, $\beta$-casein gene; DNA, deoxyribonucleic acid; IEF, isoelectrofocusing; SSCP, single-strand conformation polymorphism; RFLP, restriction fragment length polymorphism; AS-PCR, allele specific polymerase chain reaction 
\& Grosclaude, 1993; Neveu et al., 2002; Galliano et al., 2004; Cosenza et al., 2005; Caroli et al., 2006). The $C$ variant differs from $A$ in a single amino acid substitution Ala177 $\rightarrow$ Val177 of the mature protein. Mutation is not detectable on protein level (like IEF), because both amino acids are neutral, but at DNA level the protein polymorphism is identified as a nucleotide transition GCA $($ Ala177) $\rightarrow$ GTA (Val177). At this position, the A1,E, $O$, and $O^{\prime}$ alleles are all identical and therefore considered as a group and referred to as the $A$ allele (Chessa et al., 2005; Sztankoóva et al., 2008). The existence of two null alleles was confirmed by Southern and Northern blotting analyses and an allele-specific-PCR (AS-PCR) analyses were implemented to discriminate it. The first null allele in Southern Italian and the second null allele in Créole and Pyrenean breeds were detected (Mahe\& Grosclaude, 1993). These alleles are associated with nondetectable amount of this protein in milk and were characterized by mutations responsible for premature stop codons in exon 7 (Ramunnoet al., 1995; Persuy et al., 1999; Tortorici et al., 2014).

Given the strong influence of casein variants on milk composition, and being casein genes closely linked, all kinds of information regarding casein genotypes of indigenous goat populations might affect production traits and economical income for commercial goat enterprises. In the current study, the main objective was to genotype the genetic variant $\mathrm{C}$ at the goat CSN2 locus by a rapid assay using two Romanian indigenous goat breeds, which were not genotyped for these genes for the moment. The ultimate purpose was testing the feasibility and reliability of using molecular markers assisted selection in order to produce hypoallergenic organic goat milk under low input rearing conditions.

\section{MATERIAL AND METHODS}

For the current study, 73 Banat's White (Fig. 1.) and 82 Carpatina (Fig. 2.) purebred goats were randomly selected from 8 herds ( 3 for Banat's White and 5 for Carpatina) located in different areas of Arad, Timis and Caras-Severin counties in Western Romania. All flocks were included in the official performance recording schemes, with the ancestry of the animals being known for at least two generations. The three Banat's White flocks were included in the breed's conservation plan, as national gene reserve farms.

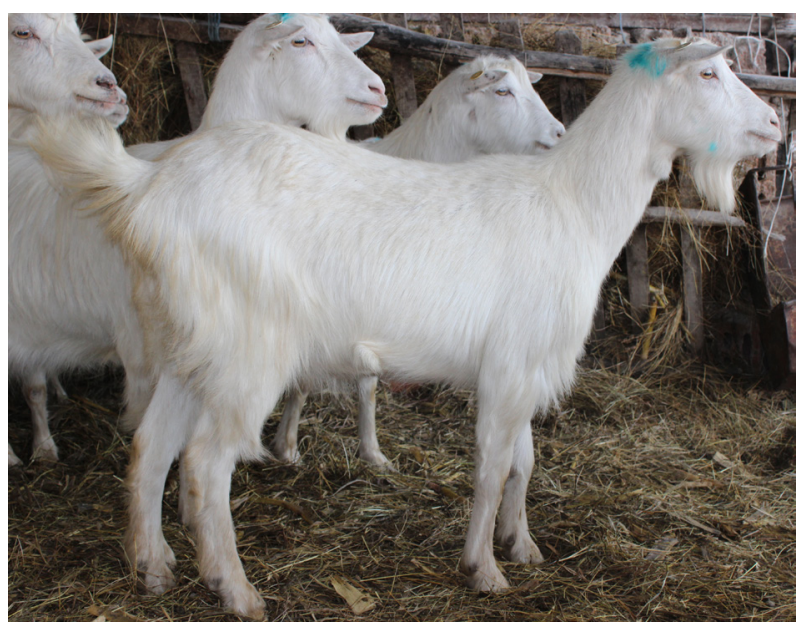

Figure 1. Banat's White doe, sampling site: Lugoj, Timis county
Hair follicle samples were taken from each animal and genomic DNA was extracted with the method described in FAO/IAEA (2004). DNA was stored at $-20^{\circ} \mathrm{C}$ until further analysis. DNA concentration was measured with NanoDrop Spectrophotometer (Thermo Scientific, USA) and diluted to $50 \mathrm{ng}$.

For the rapid genotyping of the nucleotide substitution GCA (Ala177) $\rightarrow$ GTA (Val177) (reference sequence AJ011018.3 from GenBank[www.ncbi.nlm.nih.gov]) the TaqMan (Applied Biosystems, USA) genotyping assay was designed using the following primers and probe: forward primer: 5'-CT'T TCT CCA ACC GTC ATG TT'T-3', reverse primer: 5'-ACA AAA AAA TCA ATA ATG AAT GGT TC-3', probe C/A: CCCCAGAAAGCAGTGCCCC. Real-time PCR was performed in $20 \mu \mathrm{l}$ reactions with $10 \mu \mathrm{l}$ TaqMan PCR Master Mix containing AmpliTaq Gold DNA Polymerase (Applied Biosystems, USA), 10 pmol concentration of forward and reverse primer, $10 \mathrm{pmol}$ of probe and $1 \mu \mathrm{l}(50 \mathrm{ng})$ of genomic DNA as template. Amplification, detection and allelic discrimination were performed on ABI 7300 Real-Time PCR System (Applied Biosystems, USA) in 96-well reaction plate. PCR conditions were as follows: $10 \mathrm{~min}$ at $95^{\circ} \mathrm{C}, 40$ cycles of $15 \mathrm{sec}$ at $95^{\circ} \mathrm{C}$ and $1 \mathrm{~min}$ at $60^{\circ} \mathrm{C}$. Negative control with distilled water instead of DNA from goat sample was run in each assay.

Allelic discrimination analysis was performed using SDS software (Applied Biosystems, USA). With SDS software the results of allelic discrimination run were plotted on a scatter plot of allele $A$ versus allele $C$, according to the differences in the extent of reporter dye fluorescence intensity after PCR amplification. Thereby, samples were automatically grouped according to their genotypes. The results of the TaqMan allelic discrimination assay were graphically interpreted and all of the samples were correctly assigned to the genotype.

The research activities were performed in accordance with the European Union's Directive for animal experimentation (Directive 2010/63/EU).

\section{RESULTS AND DISCUSSIONS}

The C>A mutation of the goat CSN2 gene was investigated through a rapid and sensitive molecular genotyping assay. Optimization of the'TaqMan probe to dif-

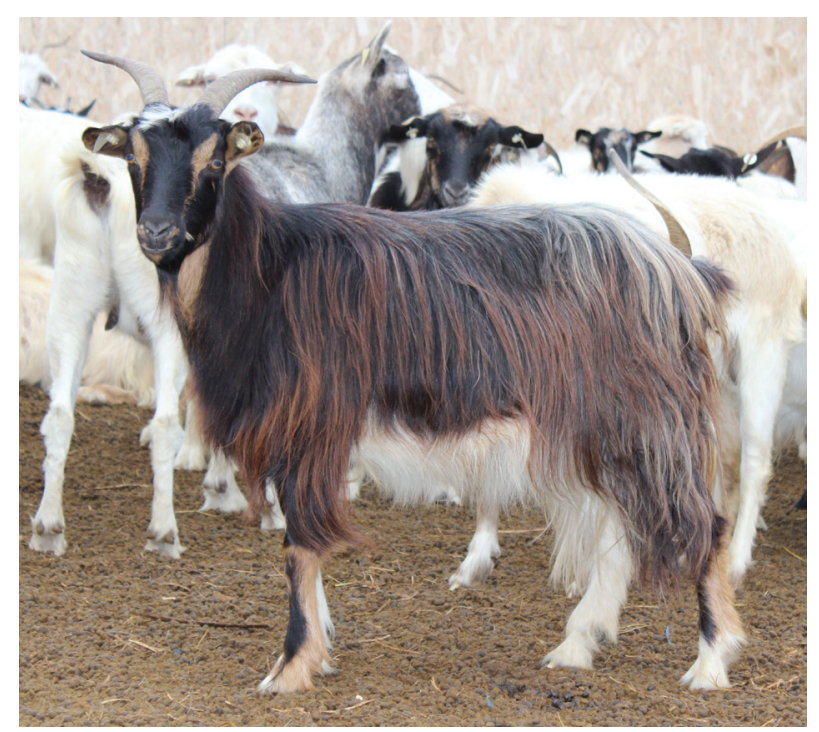

Figure 2. Carpatina doe, sampling site: Secas, Timis county 


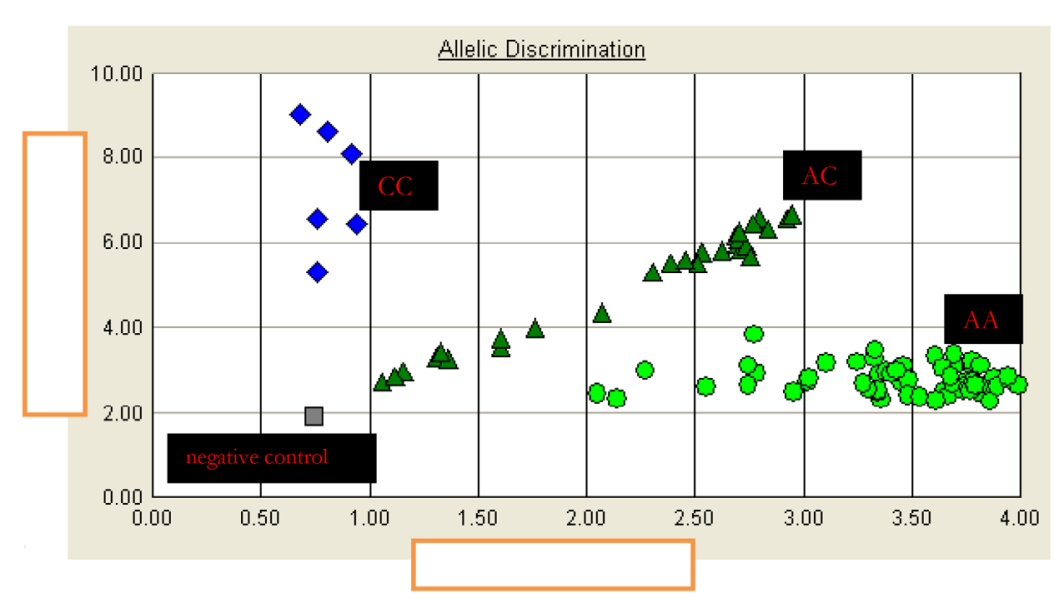

Figure 3. Different genotypes at the caprine CSN2 locus $(\bullet)$ CC homozygotes; $(\bullet)$ AA homozygotes; $(\mathbf{\Delta})$ heterozygotes; $(\boldsymbol{\square})$ negative control

by the heterozygous genotype $A C$ $(47.95 \%)$, whereas the homozygous genotype $A A(2.73 \%)$ had the lowest frequency. Similar results were obtained in Czech White shorthair goat breed (Sztankoova et al., 2008). In the case of Carpatina breed, the heterozygous genotype $A C$ had the greatest frequency $(63.41 \%)$ followed by the homozygous CC (19.51\%) and $A A(17.08 \%)$ genotypes (Table 1). These frequency values were similar to those previously found in Czech Brown Shorthair goats and Italian goat populations (Sztankoova et al., 2008; Chessa et al., 2005; Caroli et al., 2006; Tortorici et al., 2014).

\section{CONCLUSIONS}

In the current preliminary study ferentiate $A$ and $C$ allele was successfully performed by following the manufacturer instruction (Fig. 3.). All three genotypes ( $A A, A C$ and $C C$ ) and the negative control were clearly separated based on the different intensity of the alleles. Thereby, the TaqMan assay proved to be the rapid and sensitive method for identification of goat CSN2 genotypes and discrimination of $A$ and $C$ alleles.

The frequencies of $A$ and $C$ allele were similar in Carpatina while $C$ allele was more frequent in Banat's White (Table 1).

Table 1. Frequency of genotypes and alleles of Banat's White and Carpatina goat

\begin{tabular}{lllllll}
\hline \multirow{2}{*}{ Breed } & Genotype & Number & Frequency of genotype & Allele & Frequency of allele \\
\hline \multirow{3}{*}{ Banat's White } & CC & 36 & 49.32 & C & 0.73 \\
\cline { 2 - 6 } & AA & 2 & 2.73 & A & 0.27 \\
\hline \multirow{5}{*}{ Carpatina } & CA & 35 & 47.95 & & \\
\cline { 2 - 7 } & CC & 16 & 19.51 & C & 0.51 \\
\hline & CA & 52 & 63.41 & A & 0.49 \\
\hline
\end{tabular}

In comparison with other studied goat breeds, in the genotyped Carpatina goat populations from the southwest part of Romania a similar higher frequency of the $C$ allele compared to $A$ allele was observed, as previously reported for the Tunisian Arbi goat and South Italian, Sicilian breeds (Saanen, Maltese, Derivata di Siria, Garganica, Jonicaand Cilentana) (Vacca et al., 2009; Sacchi et al., 2005; Chessa et al., 2005; Gigliet al., 2008). At the CSN2 locus $C$ variant was dominant in Banat's White goats (0.73) in comparison to allele $A$ (0.27). Similar results were reported in Czech dairy goats $(0.669$ and 0.331 , respectively) and for the indigenous Italian Orobica breed (0.975) using Light Cycler and PCR-SSCP analysis (Sztankoóva et al., 2008; Chessa et al., 2005). IEF method was not efficient at separating $A$ and $C$ allele in Romanian Carpatina breed because of their identical isoelectric point (Vlaic et al., 2010).In contrast, in most Italian goat breeds, the allele $A$ had greater frequency (Caroli et al., 2007), as in Turkish, Indian, Sudanese (Chessa et al., 2007) and Hungarian indigenous breeds.

In the Banat's White goat breed, the most frequent genotype was the homozygous CC $(49.32 \%)$, followed the main aim was to present the allele and genotype frequencies of CSN2 variants in Romanian indigenous goat breeds (Banat's White and Carpatina) using a rapid assay. The high frequency of the $C$ allele in both studied populations was similar to those previously reported in other indigenous European breeds. The results could prove useful for the goat dairy industry and should be utilised for genetic improvement of Romanian dairy goat breeds.

Our future plan is to perform association studies between genotype and milk yields, protein and lactose content, in order to assess if subsequent impact on such production traits exist. Furthermore, the ultimate aim is to assess the feasibility of including molecular markers in the selection schemes for the Romanian indigenous goat breeds with weak alleles and null genotypes at CSN2 locus, in order to produce hypoallergenic milk and dairy products. Based on our initial results, it is still to be elucidated which of the studied breeds is more suitable for the mentioned dairy products. However, we do know that the used method is rapid and efficient for genotyping the studied breeds for the weak and 0 alleles as well. Moreover, the presented results brought some information about the breeds and suggest that there is a genetic basis for molecular marker assisted selection in the breeds, and that such trait could be included in the breeds' selection index.

\section{Acknowledgements}

This work was supported by a grant of the Romanian National Authority for Scientific Research and Innovation, CNCS - UEFISCDI, project number PN-II-RUTE-2014-4-0023.

\section{REFERENCES}

Caroli A, Chiatti F, Chessa S, Rigagnese D, Bolla P, Pagnacco G (2006) Focusing onthe goat casein gene complex. J Dairy Sci 89: 3178-3187. http://doi:10.3168/jds.S0022-0302(06)72592-9.

Chessa S, Budelli E, Chiatti AM, Cito P, Bolla P, Caroli A (2005) Predominance of $\beta$-casein (CSN2) $\mathrm{C}$ allele in goat breedsreared in Italy. 
J Dairy Sci 88: 1878-1881. http://10.3168/jds.S0022-0302(05)728630 .

Chessa S, Rigagnese F, Küpper J, Pagnacco G, Erhart G, Caroli A (2008) Short communication: the $\beta$-casein (CSN2) silentallele C1 is highly spread in goat breeds. J Dairy Sci 91: 4433-4436. http:// 10.3168/jds.2008-1228.

Chianese L, Caira S, Garro G, Quarto M, Mauriello R, Addeo F (2007) Occurrenceof genetic polymorphism at goat $\beta$-CNlocus. Proc. 5th Int. Symp. Challenge to Sheep and Goats MilkSectors, p 69. Alghero, Italy.

Cosenza G, Paciullo A, Gallo D, DiBerardinno D, Ramunno L (2005) A SspIPCR-RFLP detecting a silent allele at thegoat CSN2 locus. J Dairy Res 72: 456-459. http://10.1017/S0022029905001342

Dragomir N (2009) Multifunctional utilization of pastures in Romania. Sci Pap Anim Sci Biotech 42: 191-194.

FAO/IAEA (2004) Agriculture Biotechnology Laboratory - Handbook of Laboratory Exercises. IAEA Laboratories, p 18. Seibersdorf, Austria.

Galliano F, Saletti R, Cunolo V, Foti S, Marletta D, Bordonaro S, D'Urso G (2004) Identification and characterizationof a new $\beta$-casein variant in goat milk byhigh-performance liquid chromatography with electrospray ionization mass spectrometry and mass-assisted laser desorption/ionization mass spectrometry. Rapid Commun Mass Sp 18: 1972-1982.

Gigli I, Maizon DO, Riggio V, Sardina MT, Portolano B (2008) Casein haplotype variability in Sicilian dairy goat breeds. J Dairy Sci 91: 3687-3692. http://10.3168/jds.2008-106.

Hayes H, Petit E, Bouniol C, Popescu P (1993) Localisation of the alpha-S2-caseingene (CASAS2) to the homologous cattle,sheep and goat chromosome 4 by in situhybridization. Cytogenet Cell Genet 64: 282-285. http:// 10.1159/000133593.

Mahé MF, Grosclaude F (1993) Polymorphism of $\beta$-casein in Creole goatof Guadaloupe, evidence for a null allele. Genet Sel Evol 25: 403-408.

Martin P, Szymanowska M, Zwierzchowski L, Leroux C (2002) The impact ofgenetic polymorphisms on the protein composition of ruminant milks. Reprod Nutr Dev 42: 433-459. http:// 10.1051/ rnd:2002036.

Neveu C, Mollé D, Moreno J, Martin P, Léonil J (2002) Heterogeneity of caprinebeta-casein elucidated by RP-HPLC7MS: genetic variants and phosphorylations. J Protein Chem 21: 557-567.

Padeanu I (2001) Tehnologia cresterii ovinelor si caprinelor. Mirton ?. ed, p 375. Timisoara (Language?).

Pascal C, Padeanu I, Calin I, Daraban S, Nacu G (2011) Researches related to meat yield aptitudes of Carpatina breed reared in Romania. Sci Pap Anim Sci Biotech 55: 328-331.

Pascal C (2006) The morphologic and productive specific parameters of goats reared inNorth-Eastern area of Romania. In International Symposium on Goat Farming in Central and Eastern European Countries: Present and Future - IGA Regional Conference, Constanta, Romania, June 27-30. 2006, http://www.iga-goatworld.org/.

Pascal C, Confederat M (2006) Researchers with reference at the quantitative andqualitative milk production at indigenous local goats growled and exploited in the North-Estern area of Romania. In International Symposium on Goat Farming in Central and Eastern European Countries: Present and Future - IGA Regional Conference, Constanta, Romania, June 27-30, 2006. http://www.igagoatworld.org/.

Persuy MA, Printz C, Medrano JF, Mercier JC (1999) A single nucleotide delectionresulting in a premature stop codon isassociated with marked reduction of transcripts from a goat $\beta$-casein null allele. Anim Genet 30: 444-451. http://10.1046/j.1365-2052.1999.00547.x.

Raducuta I, Calin I, Purdoiu S (2012) The evolution and current situation of goat breeding in Romania. Sci Pap Anim Sci Biotech 55: 223-226.

Ramunno L, Mariani P, Pappalardo M, Rando A, Capuano M, Di Gregorio P, Cosenza G (1995) Un gene ad effetto maggiore sul contenuto di caseina $\beta$ nel lattedi capra. pp 186-186 in Proc. 11th ASPANat. Congress, Grado, Italy (in Italian?).

Rijnkels M (2002) Multispecies comparison ofthe casein gene loci and evolution ofcasein gene family. J Mammary GlandBiol 7: 327-345. http://10.1023/A:1022808918013.

Roberts B, Di Tullio P, Vitale J, Herir K,Gerdon K (1992) Cloning of the goat betacasein gene and expression in transgenicmice. Gene 121: 255-262. http://10.1016/0378-1119(92)90129-D.

Sacchi P, Chessa S, Budelli E, Bolla P, Ceriotti G, Soglia D, Rasero R, Cauvin E, Caroli A (2005) Casein haplotype structure in five italian goat breeds. J Dairy Sci 88: 1561-1568. http://dx.doi.org/10.3168/ jds.S0022-0302(05)72825-3.

Sztankóová Z, Kyselova J, Kott T, Kottova E (2008) Technical note: detection of the $\mathrm{C}$ allele of $\beta$-casein (CSN2) in Czech dairygoat breeds using Light Cycler analysis. J Dairy Sci 91: 1-5. http:// 10.3168/jds.2007-0747.

Tortorici L, Di Gerlando R, Mastrangelo S, Sardina MT, Portolano B (2014) Genetic characterisation of CSN2 gene in Girgentana goat breed. Italian I Anim Sci 13: 720-722. http:// 10.4081/ijas.2014.3414.

Vacca GM, Ben Ali OA, Carcangiu V, Pazzola M, Dettori ML (2009) Genetic structure of the casein gene cluster in the Tunisian native goat breed. Small Rumin Res 87: 33-38. http://10.1016/j.smallrumres.2009.09.034.

Vinesh PV, Biswajit B, Rupinder K, Kumar DT, Lal GS, Sachinandan D (2013) Characterization of $\beta$-casein gene in Indian riverine buffalo. Gene 527: 683-688. http:// 10.1016/j.gene.2013.06.029.

Vlaic A, Balteanu V, Pop F, Carsai T, Suteu M (2010) Milk protein polymorphisms study in some Carpathian goat populations reared in the central part of Romania. Bulletin UASVM Animal Science and Biotechnologies 67: 54-59.

Voia S, Padeanu I, Daraban S, Mot T, Dronca D, Pet I, Gavojdian D, Ivan M (2010) Study regarding goat milk composition and the growth rate in kids of Carpatina goat breed. Sci Pap Anim Sci Biotech 43: 324-327.

Zaulet M, Kevorkian S, Enache M, Ghita E, Lazar C, Rebedea M (2008) Genetic polymorhism of some proteins in the milk of Carpathian goat. Zootehnie si Biotehnologii 41: 201-207. 